Media Worlds 
This page intentionally left blank 


\title{
Media Worlds
}

Anthropology on New Terrain

\author{
EDITED BY \\ Faye D. Ginsburg, \\ Lila Abu-Lughod, \\ and Brian Larkin
}

UNIVERSITY OF CALIFORNIA PRESS

Berkeley Los Angeles London 
University of California Press

Berkeley and Los Angeles, California

University of California Press, Ltd.

London, England

(C) 2002 by the Regents of the University of California

Library of Congress Cataloging-in-Publication Data

Media worlds : anthropology on new terrain / edited by Faye D.

Ginsburg, Lila Abu-Lughod, and Brian Larkin.

p. $\mathrm{cm}$.

Includes bibliographical references and index.

ISBN $0-520-22448-5$ (Cloth : alk. paper)-

ISBN 0-520-23231-3 (Paper : alk. paper)

1. Mass media and culture. I. Ginsburg, Faye D.

II. Abu-Lughod, Lila. III. Larkin, Brian.

$\mathrm{P}_{94.6} . \mathrm{M}_{42} 6 \quad 2 \mathrm{OO} 2$

$302.23-\mathrm{dc} 21$

2002002312

Manufactured in the United States of America

$\begin{array}{llllllllll}11 & 10 & 09 & 08 & 07 & 06 & 05 & 04 & 03 & 02\end{array}$

$\begin{array}{llllllllll}10 & 9 & 8 & 7 & 6 & 5 & 4 & 3 & 2 & 1\end{array}$

The paper used in this publication meets the minimum requirements of ANSI/NISO Z39.48-1992 (R 1997) (Permanence of Paper).@ 
For Annie, Sinéad, Adrian, Justine, and Samantha, whose media worlds will be even fuller than ours. 
This page intentionally left blank 
It is often said that [media have] altered our world. In the same way, people often speak of a new world, a new society, a new phase of history, being created - "brought about"-by this or that new technology: the steam engine, the automobile, the atomic bomb. Most of us know what is generally implied when such things are said. But this may be the central difficulty: that we have got so used to statements of this general kind, in our most ordinary discussions, that we fail to realise their specific meanings. . . .

Yet all questions about cause and effect, as between technology and a society, are intensely practical. Until we have begun to answer them, we really do not know, in any particular sense, whether, for example, we are talking about a technology or about the uses of a technology; about necessary institutions or particular and changeable institutions; about a content or about a form. And this is not only a matter of intellectual uncertainty;

it is a matter of social practice.

RAYMOND WILLIAMS

Television: Technology and Cultural Form 
This page intentionally left blank 